\title{
Administrative Traditions and Economic Decision-making in South Korea
}

Tony Michell

\section{Introduction}

For the purposes of this article it is taken for granted that what occurred in South Korea (hereafter Korea) between 1961 and 1979 was government-led growth. Government-led in the sense that the government has, as actor, been pervasive in every sector of the economy. Moreover, government-led growth is taken to mean that the rate of growth of Korea would not have been so fast if the government had done less. (For a discussion of how this was done see Jones and SaKong [1980]; Michell [1984]; Westphal [1981].)

The picture of the Korean Government which has gained wide acceptance since the work of Jones and SaKong appeared is that of a hard and centralised government, the 'hard state' being the opposite of the South Asian 'soft state' which Gunnar Myrdal identifies as a major problem in Asian development [Myrdal 1968]. Other studies have assumed a centralised hierarchical society [Wade 1982]. These studies draw (usually implicitly) on concepts of Confucian society. The more the concept of a homogenous, centralised hierarchy is endorsed, the less need there is to pose the sort of analysis used in this article. All policy descends from the Blue House (the Presidential residence) and is with great promptness put into effect by the comprehensive bureaucracy.

It is commonly held that a principle objection to a high degree of state intervention in the economy is that civil servants rarely know what is best for an economy. How could the Koreans be right so often, especially in what is often described as a hierarchical system [Jones and SaKong 1980; Wade 1982]?

Here it is argued that a more careful analysis of the bureaucratic traditions and the consequent patterns of decision-making within the Korean state shows that the way in which government decisions were often, though not always, reached, involved a wide degree of opinion-taking and modifications, and even formulation of policy from the bottom rather than the top.
While no system is foolproof, this potential for consultation and modification at lower levels of the administrative structure prevents the implementation of many potentially damaging policies. At the same time the strong drive from the top, especially in the 1960 s, providing what Lewis calls the will to economise' [Lewis 1966] injected a sense of urgency and national purpose into a system which would easily have become lethargic and corrupt. A key explanation was the fact that Korean officials had a very clear aim - Korea's economic national interest - a yardstick against which all else was measured.

Some of the grosser mistakes in Korean development were in fact caused when this process was by-passed, as in the implementation of the Heavy and Chemical Industrial Plan of 1973 or where a different system prevailed, as in agriculture.

The central argument presented here is that there are four processes of decision-making in action simultaneously within the formal, ie central government, structure:

i) a hierarchical structure, in which decisions are made at the top (the process normally described);

ii) a reverse hierarchy in which decisions are made at the bottom and validated at more senior levels;

iii) an anarchic war of all against all in which conflicting decisions are made at all levels with strong competition between ministries;

iv) competing with the formal decision-making process is an informal one, which draws on traditional values of a face to face society, the rule of men rather than the rule of law [Kim Bun-woong 1982].

\section{The Heritage of the Past}

It is said of Japan that one of its characteristics is that it has brought traditional values into the modern world. What is strikingly lacking in the Korean case is a consideration of precisely what South Korea has 
inherited from its past. This is an outstanding omission from the KDI/Harvard series on the Modernisation of South Korea 1945-75, which requires rectification. The two clear values which Korea has brought to the modern world are the strength of personal relationships and the power and status of the bureaucracy. These two values owe much not only to traditional Korea, but, as will be argued, to the colonial administration of the Japanese. Both cultures are steeped in Confucianism, but very different interpretations of it.

Confucianism is not uniform throughout East Asia. Chinese, Koreans, Japanese and South East Asians have found different values in the works of the Master. The distinctiveness of Japanese Confucianism, as compared with Chinese Confuciansism, has been discussed [eg Morishima 1982], but in the English language there has been only inadequate treatment of the distinctiveness of Korean Confucianism [Palais forthcoming]. Compared with Japan, Confucianism has not strengthened Korean nationalism either in the Yi dynasty or now. Whereas in Japan the key confucian value of loyalty was focused - at least in the higher levels of society - on the feudal lord or territory and could be turned into loyalty to the Emperor or the firm, in Korea loyalty was always focused primarily on the family.

Korea in the 1960s, 1970s and 1980s is, of course, sub confucian. Knowledge of the confucian classics is extremely limited and the traditional confucian schools that continued a precarious existence into the 1960s have been by-passed by the all-intensive pressure of the university entrance examination and extra curricula pressures.

Confucianism therefore continues at a non-explicit level in social customs and to the degree that confucian values have been deliberately inserted into the educational system. There is a further important point which must be stressed. Koreans are brought up to be deferential to elders and betters - deference to position, age, sex, but not particularly to authority in the abstract. Throughout the Yi dynasty there was a strong appeal to the inner concept of what is right (kunja li) rather than constituted authority. Moreover, although the traditional Korean state had the structure of a centralised and hierarchical state, it did not function that way. The king was a prisoner of ritualised procedure and within the carefully graded hierarchical structure a large degree of autonomy was given to specific officials. The real hierarchical distinction was between yangban ${ }^{1}$ and others. Within the elite a wide range of dissent and autonomy was

\footnotetext{
The yangban were the traditional elite, sometimes translated as gentry, but actually holding theoretical status by virtue of having passed the civil service examination.
}

tolerated because all were kunja. Amongst the others not even the slightest dissent was permitted.

Finally, although Koreans are taught to be deferential to elders and betters and patronising towards youngers and 'worsers', they never feel comfortable when deferring. Confucian respect is based on tension, and a major aim is to establish a relationship in which a Korean can feel pyon ha da (comfortable, relaxed). The only group in which this is possible is in the age cohort or peer group. These tensions are apparent in Japanese society and can partly be released through the concept of amae, the possibility of relaxing in front of superiors. Park was quick to point out that amae was not unique to the Japanese, but that the concept existed in Korea as well. It is essential to the workings of a confucian society.

If the Yidynasty heritage has been misunderstood, the Japanese legacy has been ignored. The bureaucracy was heir to the full veneration of Yi dynasty times in which official office was the goal of every member of the $y$ angban class. But it is important to remember that the old bureaucracy came to an end in 1910. The post 1945 bureaucracy was the successor, not of the Yi dynasty bureaucracy but of the Japanese colonial administration

In 1945 those who had been junior officials in the colonial administration moved up to all but ministerial posts. The post 1945 bureaucracy was therefore deeply imbued with Japanese administrative values. This included a sense of corporate loyalty which has lasted to the present day. A man is always an EPB (Economic Planning Board) man, or an MCI (Ministry of Commerce and Industry) man, even if he changes ministries. This sense of corporate loyalty is much stronger in government ministries than in any other part of Korean life.

The opposition called for a trial of collaborators, but such cries were swept aside. The Americans offered many suggestions for administrative arrangements, but few if any were adopted. It must be remembered that the American administration lasted only from 1945-48 and had much less clear goals than in Japan. Even in Japan they proved unable to change the Japanese way of thinking, as is abundant in the Yoshida memoirs [Dower 1978]. In Korea they did not try, merely attempting to set up a viable government when many of the political leaders were excluded.

Even if it can be shown that the Americans tried hard - and the definitive history of the American occupation has yet to be written - the linguistic barrier prevented effective communication of ideas and bureaucratic moves. Perhaps the most striking example was the foundation of the MCI. In Japan the Americans were determined to destroy this ministry, 
creating a rapid contraction and a renaming to Ministry of International Trade and Industry (MITI). Chalmers Johnson has recently shown the extent to which this aim was perverted by the existing staff [Johnson 1982].

In Korea MCI retained the same Chinese characters as the abolished Japanese ministry. How little the incoming government understood how the bureaucracy worked can be seen from Syngman Rhee's appointment of Louise Yim as first Minister of MCI. When Yim protested she know nothing of trade or industry, Rhee is supposed to have replied 'actually, the Minister does not have to run the industries or business of Korea. The Minister has to inspire greater production and get foreign investments into the country. The people would listen to you and work for you and your foreign contacts would be useful'.

This was not the way MCI officials thought, and they proceeded to run the country as it had been run in the past. This heritage was primarily that of the wartime economy, full of administrative guidance and government regulation. The 1948 Constitution gave the government sweeping powers to run the economy and $\mathrm{MCI}$ was trained to use those powers. So too, in agriculture. During the wartime economy 1937-45, the Japanese had built up an all-powerful Ministry of Agriculture and Fisheries which reached into the very roots of the countryside through the National Agricultural Cooperative Federation (NACF).

Thus in the case of two of the four overlord ministries of the post-1961 era the groundrules followed the Japanese model from the beginning. The same was true of the Ministry of Transport, even down to MOT running tourism because Chosun Railways had been run by South Manchurian Railways which had been responsible for tourism. The Ministry of Communications inherited the postal system, the Monopoly Office the salt, ginseng and tobacco monopolies, the Ministry of Home Affairs inherited the police. Even in the Finance Ministry the system appears to have been continued within a Japanese style framework, even though the new government had to cope with massive inflation and the conversion from the Japanese currency to a Korean currency.

Contrast this with the situation in North Korea. North Korea did not control any of the former central government or records higher than provincial records. Even if North Korea had wished to set up a government paralleling that in South Korea the personnel did not exist in the North. In the North quite different traditions could emerge in the bureaucracy.

Once the Korean war had begun it was clear new institutions would be required. A new ministry, the
Ministry for Reconstruction, was created in 1951, and new financial institutions, notably the Korean Reconstruction Bank (apparently modelled on the Japanese Reconstruction Bank of 1945) now the Korean Development Bank. The Ministry of Reconstruction was to be not so much a planning ministry as an implementation ministry.

This was to be the key characteristic of the Korean governmental system, that all ministries were implementing ministries first and planning ministries second. Even when planning came into fashion in the 1960 s planning and implementation were never separated. In the subsequent sections it will be seen that even planning does not come from the top, and implementation never does.

\section{The Park Reforms}

The system of the 1950s did not produce high growth. What was lacking was essentially the drive to economise, the sense of economic development as being the major priority, and it was this goal which Park Chung-hee introduced. It is important to contrast this desire with the situation in many other developing countries where the elite already enjoy a high standard of living and the desire for national economic development takes second priority to a comfortable life. What is needed is the strong sense of economic nationalism which was the contribution of Park Chung-hee.

From the structural point of view what was needed was a strong overlord planning ministry and an overlord implementation ministry, the Economic Planning Board (EPB) and the Ministry of Construction. Unlike so many countries, planning was not to be placed in an advisory agency, but at the core of the ministry which would also handle the budget, foreign aid and loans (since the balance of payments was the major constraint) and control the collection of national statistics. These functions were collected from various ministries to form the EPB whose head would always be the Deputy Prime Minister.

The Ministry of Construction came in 1963 using a translation of the Japanese legislation setting up the Japanese Ministry of Construction. This would be charged with national physical planning and construction itself, uniquely having provincial offices of construction.

One further move was to create immediately industry associations at a level corresponding to SITC 4 digit industrial classification. These look very like the 'Self Control Associations' of the Japanese wartime economy [Johnson 1982: 162-5] except that by making them four digit rather than three digit, they are much less powerful and more subservient to government 
pressure. In the later 1960 s it became clear that this was an inefficient level, and for key industries such as machinery and text iles two or three digit organisations were created.

\section{Who Makes the Economic Decisions?}

The description given so far suggests a complicated system of government agencies operating within a cultural and historical context which gives individual bureaucrats considerable freedom of action. It is argued that the Korean Government is very far from being a monolithic and hierarchial organisation. This is not to say that it cannot, on occasion, function like one, but that it cannot sustain the effort. In the Weberian sense one does not find a hierarchy working 'by assigning work and validating along a descending scale through the organisation'.

If one attempts a typology of decision-making this statement becomes clearer.

\section{National goals}

In the broadest sense these come from the top. However, in the broadest sense they are merely slogans. In most cases these national goals come from a wide range of sources including, in each five year plan, a very wide consultation process which is then passed to the Council of Ministers and finally the Council of State for approval and validation, but in both cases this is a formality.

\section{National policy}

The President may indeed be concerned about inflation, but will direct ministers to work out plans, who will in turn direct their subordinates to work out a plan in the process described below. In 1978-79 pressure came from a group outside the Blue House to put control of inflation as a top priority.

\section{Sectoral plans}

Will normally be worked out by the appropriate ministry in conjunction with the relevant quasigovernmental agencies.

\section{Implementation}

Will be left to lower officials and not normally interferred with, which allows a wide range of informal consultation to take place.

If the small number of central government personnel were the reason for much of the decentralised decision-making, preventing senior men from having time to formulate and control policy, this still does not explain why the Koreans choose to run their organisation as they do. Given the status attached to the bureaucracy, it could have been allowed to expand to gargantuan proportions. Or it would still have been possible for the junior officials to defer to their seniors for every decision. This would of course have slowed the whole decision-taking procsss, but would have ensured a sense of hierarchy.

The important fact is that by tradition the Korean official is allowed a high degree of autonomy. This is sanctioned both by the indigenous Korean tradition and the Japanese tradition. It is quite common for a junior to impose difficulties on a member of the public within the hearing of his superior without any intervention. It appears improper for a senior to inquire uninvited into the activities of a junior. The Korean official has a degree of independence of decision-making which perhaps only the immigration official has in the British civil service.

However there is not quite the same loss of face involved in being forced to change a decision by a superior when an appeal is made to a higher level as in Japan. In this sense the Korean accepts that hierarchy does exist. In Japan it is common for companies to await the rotation of an obstinate official rather than appeal to a superior.

It is the Assistant Director (grade 4) who makes most of the day to day decisions in the government. It is openly acknowledged that it is the assistant director who 'really decides policy'. There were about 4,200 grade 4 officials in central government in 1974. It is this group who will draw up most policy measures. These measures will have little to do with neoclassical precepts, being conditioned by the dominant ethos of economic nationalism. The briefing to higher officials will be in terms of ouri nara, (our country - a key nationalist phrase in Korean thinking) and either targets already set or international comparisons.

For major policies the decisions taken at assistant director level will be presented in briefings by higher officials. The briefings take a standard form. On each page no more than three issues may be introduced as Chinese character headlines. The normal briefing would take the form of the problem (sub-divided into three sections), the situation (likewise divided), the desired goal and the appropriate policy measures. As many pages of tables as appropriate may be placed between these basic pages.

One major problem is that the Chinese headlines are ambiguous and so brief as to amount generally to empty boxes or tautologies at the level of 'inflation is caused by monetary factors'. The actual content of policy instruments therefore has to be drawn up at the more junior level. Of course policy may descend from above, as in the case of the Park reforms of 1961 or the Chon reforms of 1980: But to take the case of the March 1979 Stabilisation Measures, the direction came from the Department of the Prime Minister 
(DPM) in January that inflation must stop, but it took two months of hard work by the junior levels to work out a set of policies with this end. This involved consultation between all the economic ministries as well as major quasi-governmental agencies such as KECO (Korea Electric Company) and non-economic agencies such as the KCIA (Korean Central Intelligence Agency).

Decisions which could not be resolved by the assistant directors and directors liaising between different ministries and agencies would be settled by the Council of Economic Ministers and then placed before the President. In this process the Cabinet is not an important decision-making level.

Nor, after a decision is taken, do the consenting ministries necessarily implement it. They may delay, renege or readjust according to sectional protests without going back to the Council or even making public statements. Perhaps the best example was the resistance of the MAF to importing vegetables to meet the shortfall in 1978, so that in the end the only option was to use another government agency, OSROK (Office of Supply).

The answer to the question, who makes economic decisions, is therefore extremely complex and needs a case by case examination. 'The government' is never an adequate answer. The Ministry is rarely an adequate answer, since it will normally be a particular division of a particular bureau. In that division there will be one man charged with that responsibility. Obviously where the decision relies on implementation in the provinces, or at a local level different criteria apply. Direct implementation agencies such as NACF will be able, if the need arises, to mobilise a large number of officials.

The pressures on assistant directors do not only come from within the government. They are, as explained above, part of a web of loyalties, family, various alumni, personal and professional friendships. Thus if the implementation affects either the private or public sector, interest groups will lobby that official directly or personally known superiors rather than pressure groups. Non-direct pressure can be counterproductive, one assistant director even claiming 'every time I get a phone call from the Blue House I feel less inclined to comply'.

The informal system of personal relationships cuts across formal structures, government/business divisions in a way which in other countries would lead to widespread corruption. How is it that widespread corruption is avoided? The answer is basically through eternal vigilance and through the strong inculcation of economic nationalism - 'the will to industrialise' - into all levels of the government. In the fight against corruption the activities of the Board of Audit and Inspection which reports directly to the President and may swoop at any moment on any government ministry or quasi agency are particularly important.

\section{Conclusion}

The Korean system is therefore part planned and part the outgrowth of tradition. This preliminary account goes a long way to contradict the initial impression of a hierarchical and 'hard' state. Bureaucratic it certainly is, but the system proves highly flexible, allowing consultation at all levels and the prevention of stupid rules getting in the way of progress.

Of course 4,200 officials at grade 4 level or 12,000 over all is not a large number in the context of a nation of 30-40 million. There is still an elite which has preserved the crucial Yi dynasty distinction, not between grades of the hierarchy but between the elite and the masses. The 12,000 officials are complemented by another 50,000 in other government agencies and perhaps 50,000 in the private sector, a small enough elite to operate on a face to face basis when necessary, but a large number to be consulted on policy.

If all this is accurate, where then is the distinctiveness which made the Government of Korea such a powerful agent of development? The distinctiveness lies in several different and even contradictory sources:

i) the national consensus that economic development is paramount, beyond the interests of individual companies or power groups. If this creative nationalism were not deeply rooted in the civil service, all the potentially damaging aspects of the system described above would be actualised;

ii) the blurring of distinction between civil service and business so that at one moment a civil servant may act as a spokesman for private business and the next a private businessman may become an agent of government policy;

iii) the ability to change the nature of the structure where quick decisions are required when the fiction of a rigid hierarchy becomes a fact, for instance to raise oil prices immediately and not shelter consumers or other vested interests;

iv) decentralisation of decision-making, the fact that an assistant director can make most decisions without reference to his immediate superior can prevent administrative delay;

v) the willingness of the government to intervene whenever it felt national development would be enhanced, without regard for theoretical or ideological points. 


\section{References}

Dower, J. W., 1978, Empire and Aftermath, Harvard East Asian Monographs 84, Harvard

Johnson, Chalmers, 1982, MITI and the Japanese Miracle, Stanford University Press

Jones, Leroy and SaKong II, 1980, Government, Business and Entrepreneurship in Economic Development: the Korean case, Harvard East Asian Monographs 91, Cambridge (Mass)

Kim, Bun-woong, 1982, 'Korean bureaucracy in historical perspective' in Kim Bun-woong and Rho Wha-joon, Korean Public Bureaucracy, Kyobo Publishing, Seoul

Lewis, W. A., 1966, Development Planning, Allen and Unwin, London
Michell, Tony, 1984, 'Trade, industrialisation and employment in the Republic of Korea', ILO World Employment Programme, Geneva

Morishima, M., 1982, Why Has Japan 'Succeeded': Western technology and the Japanese ethos, Cambridge University Press

Myrdal, G., 1968, Asian Drama, Allen Lane, The Penguin Press, London

Palais, James $\mathrm{T}$., forthcoming, 'The Confucian bureaucracy in Korea', Journal of Asian Studies

Wade, Robert, 1982, Irrigation and Agricultural Politics in South Korea, Westview Press, Boulder (Co)

Westphal, Larry E., 1981, 'Empirical justification for infant industry protection', Staff Working Paper no 455, World Bank, Washington 